\title{
Application of general method for design of concrete columns and encased composite steel and concrete columns
}

\section{Aplicação do método geral para dimensionamento de pilares de concreto e pilares mistos de aço e concreto totalmente revestidos}
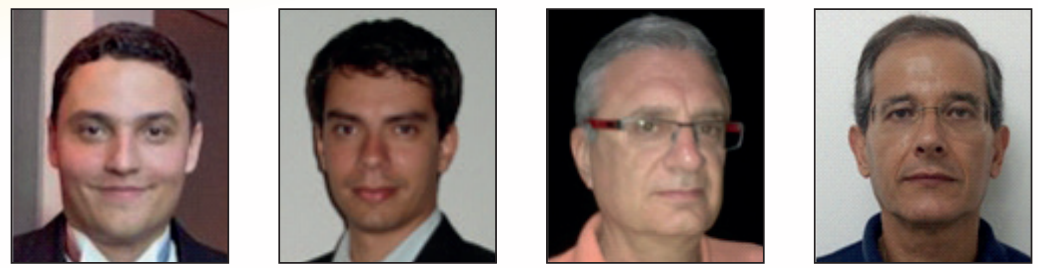

L. E. A. CHAVES a lechaves@gmail.com

R. B. CALDAS a caldas@dees.ufmg.br

R. H. FAKURY a fakury@dees.ufmg.br

R. J. PIMENTA b roberval@codeparsa.com.br

\begin{abstract}
The purpose of this work is the development and implementation of a numerical procedure for the design of reinforced concrete columns (RC) and composite columns with fully concrete encased steel I-section (SC). For this purpose, a computer program was developed to determine the load capacity of these columns, applying the General Method adopted by ABNT NBR 6118:2014. The program is based on an iterative process from integration of the curvatures along the column, obtained by determining the moment-curvature relationship of the cross section by the Newton-Raphson method. Several experimental and numerical results are compared to the program's to demonstrate the accuracy of the procedure.
\end{abstract}

Keywords: reinforced concrete columns, composite steel and concrete columns, general method.

\section{Resumo}

O propósito deste trabalho é o desenvolvimento e implementação de um procedimento numérico voltado para o dimensionamento de pilares de concreto armado e pilares mistos de aço e concreto totalmente revestidos. Assim, foi desenvolvido um procedimento computacional para a determinação da capacidade resistente desses pilares, a partir do Método Geral adotado pela ABNT NBR 6118:2014. O programa emprega um processo iterativo a partir da integração das curvaturas ao longo do pilar, obtidas através da determinação da relação momento-curvatura da seção transversal pelo método de Newton-Raphson, com base em um modelo discreto de fibras. Diversos resultados numéricos e experimentais são utilizados em comparações para comprovação da eficácia do procedimento implementado.

Palavras-chave: pilares de concreto armado, pilares mistos de aço e concreto, método geral. 


\section{Introduction}

The purpose of this work is the development and implementation of a general procedure for the design of reinforced concrete columns (RC) and composite columns with fully concrete encased steel I-section (SC).

A calculation model in accordance with the ABNT NBR 6118:2014 [1] General Method was implemented in order to evaluate the bearing capacity of reinforced concrete columns and composite columns according to the same parameters comparisons.

The program is based on an iterative process from integration of the curvatures along the column, obtained by determining the moment-curvature relationship of the cross section by the NewtonRaphson method, based on a discrete fiber model. Several experimental and numerical results are compared to the program's to verify the efficiency of the procedure.

\section{Computational implementation}

The program CSTMI, Calculation of Composite Cross Sections, was developed by Caldas and Sousa Jr. [2] with the purpose of analyzing generic composite cross sections at ambient (Caldas [3]) and elevated temperature (Caldas [4]).

The main algorithms implemented in CSTMI are: algorithms for obtaining moment-curvature relationship; algorithms for obtaining the deformed cross section according to the applied axial force and moments; algorithms for obtaining axial force-moment interaction surface and interaction surface of moments for a given axial force; and algorithms for obtaining 3D surface interaction to axial force and moments.

A fiber model is applied in the program for the integration of stresses and determination of resistances. In general, this method consists of discretization of the cross section in small elements (called fibers), and each of them can assume a constitutive model.

The stress-strain relationships for concrete and steel are considered according to ABNT NBR 6118:2014 [1]. The reinforcing steel properties are considered separately and are not included in the fiber mesh. Simply put, the concrete areas occupied by reinforcements are not deducted from the discretized cross section. All meshes are generated with the assistance of GMSH program [5], which uses a text output from CSTMI as geometry data entry and discretizes the cross section to elements of three and four sides. The program interface for columns calculation developed for this study and the discretized cross section are shown in Figure 1.

The solution by the General Method consists of finding the equilibrium of internal forces to external forces applied in all cross sections along the column, considering the effects of material and geometric nonlinearity.

Only columns subjected to axial load and moment about one axis were considered in this study. The methodology to calculate columns is based on the numerical integration of the curvatures obtained from moment-curvature relationship. Thus, the program obtains an initial displacement of the column, leading to its deformed shape. The process is then repeated, considering the second order effects, until the convergence of displacements, subsequently getting a final equilibrium setting.

\section{Figure 1 - Columns calculation interface of CSTMI}

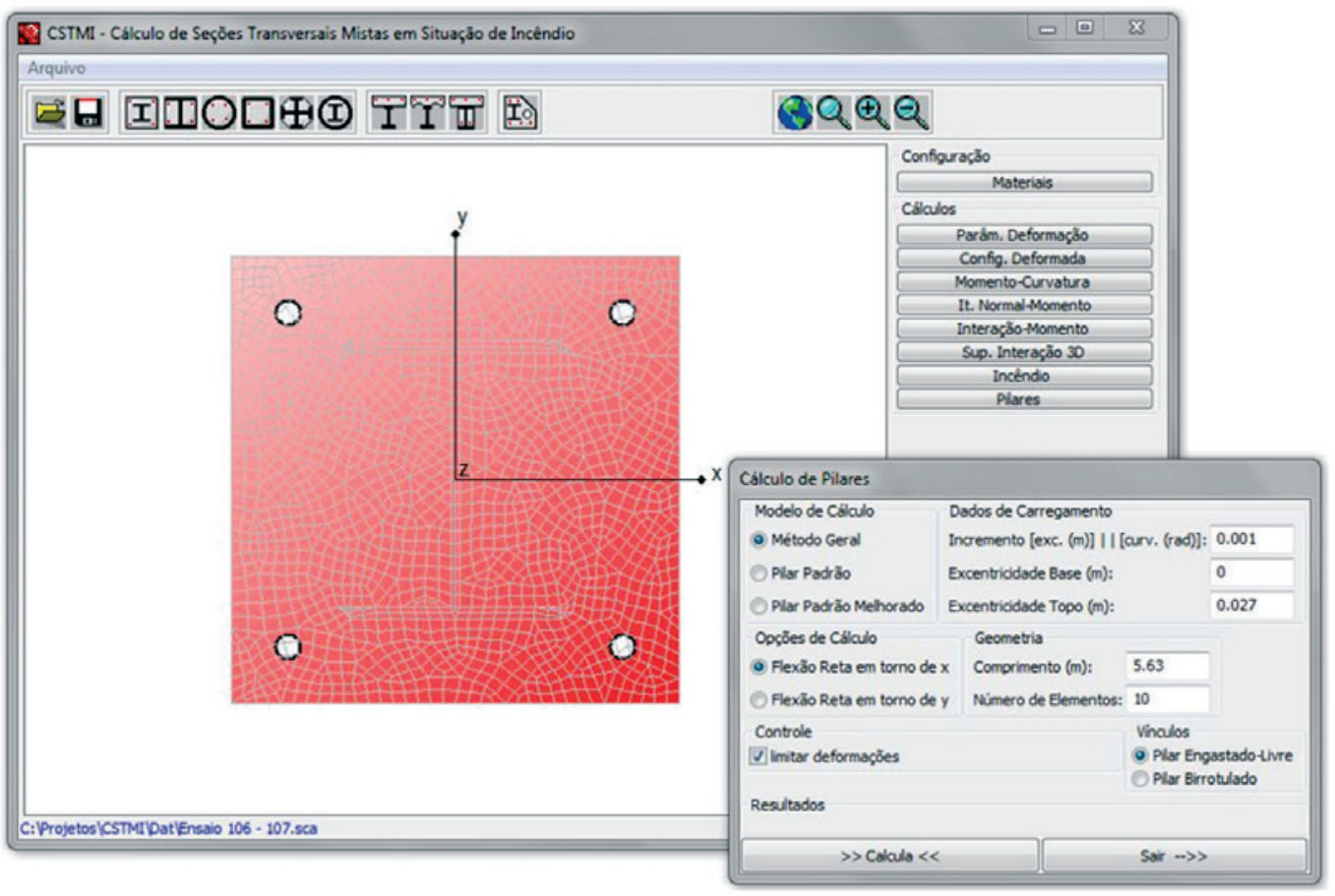




\section{Figure 2 - Bar discretization and applied moments}

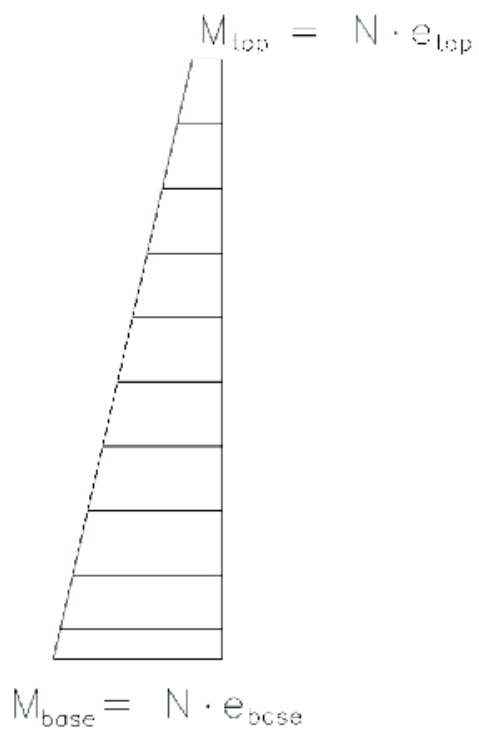

Using the Newton-Raphson method, Caldas [3] has implemented an algorithm for determining the moment-curvature relationship by the control of applied moments (load control), given by increments of applied moment in the section.

In the implementation of this work the geometry of the column is simplified as a bar formed by a finite number of elements informed by the program user, as shown in Figure 2 . The calculations of the equilibrium section are performed for each node of the bar.

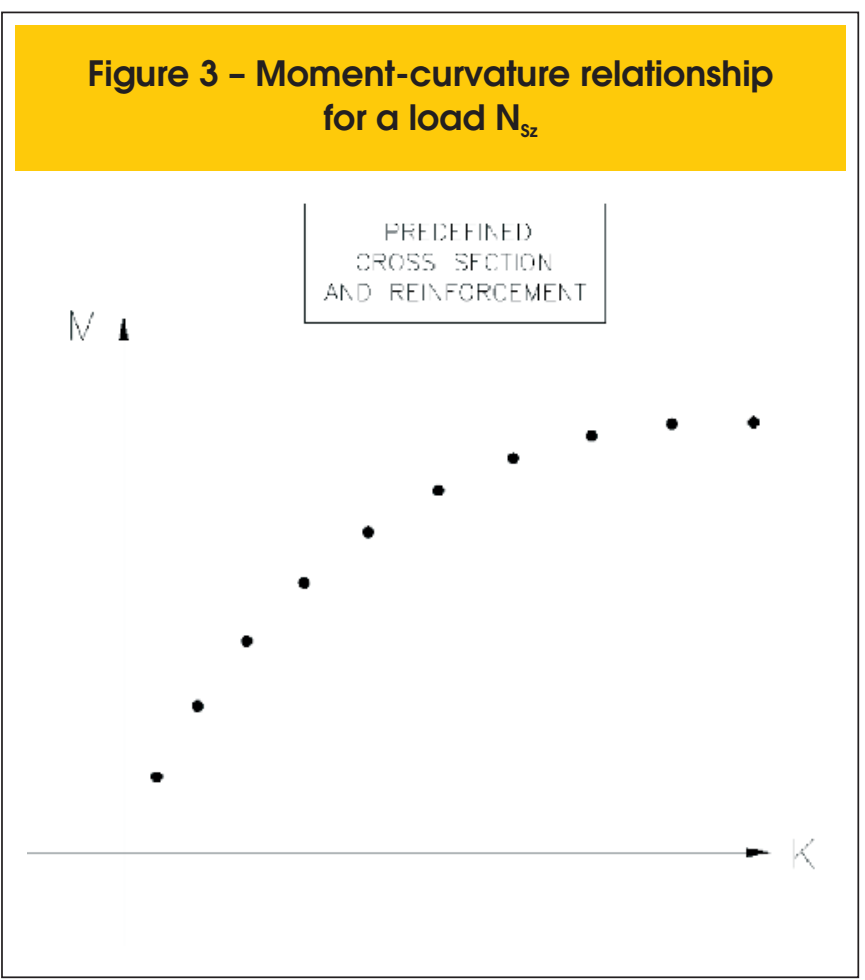

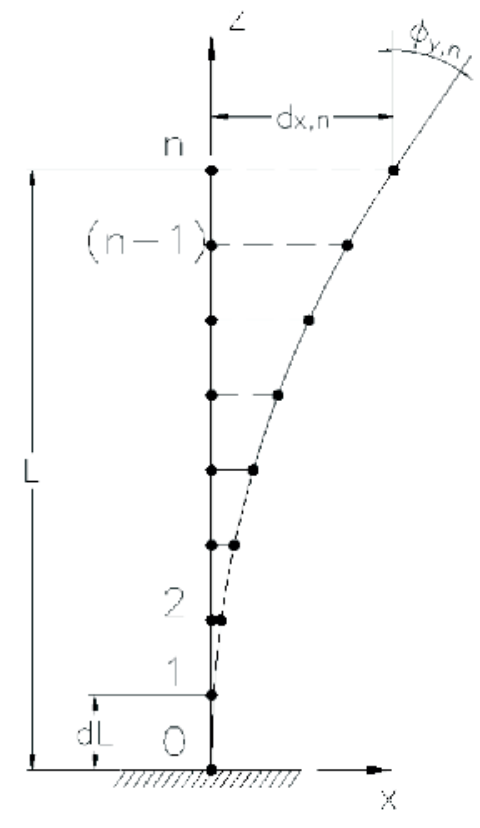

Consider a restrained-free column with predefined cross-section and reinforcement subjected to an axial compressive load $\mathrm{N}_{\mathrm{Sz}}$. By the load control algorithm, the program obtains a moment-curvature relationship as shown in Figure 3.

It is considered that the moments are applied only at the ends of the bar, by top and base eccentricity as shown in Figure 2. The axial force and moments (only about one axis) are applied to the geometrical center of the cross section and balanced on each node of the bar, so the accuracy of the model increases as more elements are used.

The applied moment of the bar at undeformed condition, on each node $\mathrm{i}$, can be written as:

$$
M_{i}=M_{\text {base }}+\left(M_{\text {top }}-M_{\text {base }}\right) \frac{Z_{i}}{L}
$$

where $\mathrm{M}_{\text {base }}$ and $\mathrm{M}_{\text {top }}$ are, respectively, the moments applied at the base and top of the column; $z_{i}$ is the element position; and $L$ is the length of the bar.

The program builds a position vector with the coordinates of the nodes and a vector with the applied moments corresponding to them. By introducing each point of the vector of applied moments at the moment-curvature relationship and interpolating linearly, the program obtains a vector with the corresponding curvatures for each node of the bar.

The rotation $\phi_{y}(z)$ of the cross section at any point can be obtained by integrating the curvatures $k(z)$ along the length of the bar:

$$
\phi_{y}(z)=\int_{0}^{L} k_{y}(z) d z+C_{1}
$$


Applying the boundary condition $\phi_{\mathrm{y}}(0)=0$ in equation (2) leads to $C_{1}=0$. Numerically, the integration of curvature is obtained by the sum of the areas under the graph formed by the points of the curvatures vector.

From the integration of the curvatures the program builds a vector with the rotations $\phi_{i}$ of the nodes obtained with equation (3):

$$
\phi_{i}=\phi_{i-1}+\frac{k_{i}+k_{i-1}}{2}\left(z_{i}-z_{i-1}\right)
$$

where $k_{i}$ and $k_{i-1}$ are, respectively, the curvatures at the availed and at the previous node; $z_{i}$ and $z_{i-1}$ are respectively the positions of the availed and of the previous node; and $\phi_{\mathrm{i}-1}$ is the rotation of the previous node. The equation (3) is valid for $i \geq 1$. The node 0 has null rotation, $\phi_{y}(0)$, which is determined by the boundary conditions. The transversal displacement $d_{x}(z)$ of the column's axis is obtained by double integration of the curvatures, ie., by simple integral of the rotations of the cross section, according to equation (4):

$$
\mathrm{d}_{\mathrm{x}}(\mathrm{z})=\int_{0}^{\mathrm{L}} \phi_{\mathrm{y}}(\mathrm{z}) \mathrm{dz}+\mathrm{C}_{2}
$$

Applying the boundary condition $d_{x}(0)=0$ in equation (4) leads to $\mathrm{C}_{2}=0$. The reasoning for obtaining numerical integration of the rotations is identical to that used for the integration of curvatures.

\section{Figure 4 - Symmetry condition for simple supported columns}

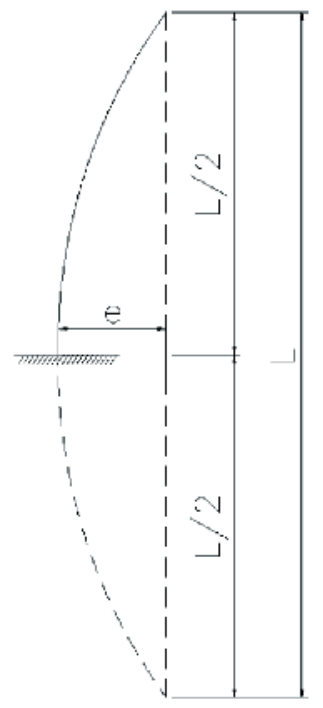

The program builds a vector with the displacements of the nodes, given by:

$$
\mathrm{d}_{\mathrm{i}}=\mathrm{d}_{\mathrm{i}-1}+\frac{\phi_{\mathrm{i}}+\phi_{\mathrm{i}-1}}{2}\left(\mathrm{z}_{\mathrm{i}}-\mathrm{z}_{\mathrm{i}-1}\right)
$$

where $\phi_{i}$ and $\phi_{i-1}$ are, respectively, the rotations at the availed and at the previous node; $z_{i}$ and $z_{i-1}$ are, respectively, the positions of the availed and of the previous node; and $\mathrm{d}_{\mathrm{i}-1}$ is the displacement of the previous node.

Then, it is obtained by this process the deformed position of the cross sections at the nodes from the undeformed position. A second iteration is executed from the deformed position of the column, now considering the additional effects due to the column's displacement (second order effects). The applied moment in the deformed condition at node $i$ is given by:

$$
M_{i}=M_{\text {base }}+\left(M_{\text {top }}-M_{\text {base }}\right) \frac{Z_{i}}{L}+N_{s z}\left(d_{n}-d_{i}\right)
$$

where $d_{i}$ is the displacement obtained at the previous iteration for the node under consideration; and $d_{n}$ the displacement obtained at the previous iteration to the top of the column.

The increase of the applied moments in the second iteration results in a new deformed configuration of each cross section of the bar, which, in turn generates a new displaced position of the nodes and increases their moments. This process is repeated until the occurrence of one of the following situations:

a) convergence of the procedure for a given tolerance;

b) instability of the bar by excessive displacement;

c) failure of the material due to the occurrence of stresses exceeding the standards limits.

It was observed that the occurrence of items $b$ and $c$ is perceived by the fact that the applied moment considered is above the moment-curvature relationship, not being possible in this case to get a curvature corresponding to the moment.

The same formulation of restrained-free columns is adopted for the calculation of simple supported columns, but it uses half of the bar length value in the calculations (Figure 4), since the buckling coefficient $\mathrm{K}$ of those columns is equal to 1.0, compared to the value of $K=2.0$ in restrained-free columns. It is emphasized that this symmetry condition must also be assumed to the applied diagram of bending moments.

Based on this iterative process, it is possible to identify if the column resists the axial force and moments applied.

To obtain the column resistance, it was developed a second algorithm based on the plastic resistance of cross section and repeating the foregoing process. First, the plastic resistance of the cross section in axial compression, $\mathrm{N}_{\mathrm{REF}}$, is obtained by:

$$
N_{\text {REF }}=A_{a} f_{y a}+A_{c} f_{c k}+A_{s} f_{y s}
$$


Table 1 - Comparison of resistance for reinforced concrete columns by tests and CSTMI

\begin{tabular}{|c|c|c|c|c|c|c|c|c|c|c|c|c|c|c|c|c|c|c|}
\hline Authors & \multicolumn{2}{|c|}{$\begin{array}{l}\text { Column } \\
\text { (exp1; } \\
\text { exp2) }\end{array}$} & \multirow{2}{*}{$\begin{array}{l}\text { Base } \\
(\mathrm{cm}) \\
7,62\end{array}$} & \multirow{2}{*}{$\begin{array}{c}\text { Height } \\
\text { (cm) } \\
7,62\end{array}$} & \multirow{2}{*}{$\begin{array}{c}\text { Number } \\
\text { of bors }\end{array}$} & \multirow{2}{*}{$\begin{array}{c}\begin{array}{c}\text { Unitary } \\
\text { As }\left(\mathrm{cm}^{2}\right)\end{array} \\
0,355\end{array}$} & \multirow{2}{*}{$\begin{array}{c}\begin{array}{c}\text { Total As } \\
\left(\mathrm{cm}^{2}\right)\end{array} \\
1,42\end{array}$} & \multirow{2}{*}{$\begin{array}{c}\begin{array}{c}\text { Cover } \\
\text { (cm) }\end{array} \\
1,27\end{array}$} & \multirow{2}{*}{$\begin{array}{c}\mathrm{L} \\
(\mathrm{cm}) \\
182\end{array}$} & \multirow{2}{*}{$\begin{array}{l}\text { fc } \\
(\mathrm{MPa}) \\
19,9\end{array}$} & \multirow{2}{*}{$\begin{array}{c}\begin{array}{c}\text { fy } \\
(\mathrm{MPa})\end{array} \\
352\end{array}$} & \multirow{2}{*}{$\begin{array}{c}\begin{array}{c}\mathrm{el} \\
(\mathrm{cm})\end{array} \\
3,81\end{array}$} & \multirow{2}{*}{$\begin{array}{c}\text { Fu,exp I } \\
\text { (kN) } \\
\text { 33,1 }\end{array}$} & \multirow{2}{*}{$\begin{array}{c}\text { Fu,exp } 2 \\
\text { (kN) } \\
33,4\end{array}$} & \multirow{2}{*}{$\begin{array}{c}\text { Fu,CSTMI } \\
\text { (kN) } \\
33,1\end{array}$} & \multirow{2}{*}{$\begin{array}{c}\text { Fu,CSTMI/ } \\
\text { Fu,expl } \\
1,00\end{array}$} & \multirow{2}{*}{$\begin{array}{c}\text { Fu,CSTM/ } \\
\text { Fu,exp2 } \\
0,99\end{array}$} & \multirow{2}{*}{$\begin{array}{c}\text { Fu,CSTMI/ } \\
\text { Fu,exp,mean } \\
1,00\end{array}$} \\
\hline Goyal e Jackson (7) & $\mathrm{Al}$ & $\mathrm{A} 2$ & & & & & & & & & & & & & & & & \\
\hline Goyal e Jackson (7) & $\mathrm{Cl}$ & $\mathrm{C} 2$ & 7.62 & 7,62 & 4 & 0,355 & 1,42 & 1,27 & 182 & 23,3 & 352 & 2,54 & 44,5 & 46,8 & 48,2 & 1,08 & 1,03 & 1,06 \\
\hline Goyal e Jackson (7) & El & E2 & 7,62 & 7,62 & 4 & 0,355 & 1,42 & 1,27 & 182 & 21,9 & 352 & 1,27 & 66,7 & 65,4 & 67,3 & 1,01 & 1,03 & 1,02 \\
\hline Goyal e Jackson (7) & Gl & $G 2$ & 7,62 & 7,62 & 4 & 0,355 & 1,42 & 1,27 & 182 & 22,2 & 352 & 1,91 & 55,4 & 53,0 & 55,5 & 1,00 & 1,05 & 1,02 \\
\hline Goyal e Jackson (7) & 11 & 12 & 7,62 & 7,62 & 4 & 0,25 & 1,00 & 1,27 & 182 & 22,7 & 310 & 1,27 & 60,0 & 57,4 & 58,6 & 0,98 & 1,02 & 1,00 \\
\hline Goyal e Jackson (7) & $\mathrm{K} 1$ & K2 & 7,62 & 7,62 & 4 & 0,25 & 1,00 & 1,27 & 182 & 22,8 & 310 & 1,91 & 46,6 & 45,6 & 45,7 & 0,98 & 1,00 & 0,99 \\
\hline Goyal e Jackson (7) & Ml & M2 & 7,62 & 7,62 & 4 & 0,25 & 1,00 & 1,27 & 182 & 22,9 & 310 & 2,54 & 37,1 & 37,0 & 34,4 & 0,93 & 0,93 & 0,93 \\
\hline Goyal e Jackson (7) & Ol & $\mathrm{O} 2$ & 7,62 & 7,62 & 4 & 0,25 & 1,00 & 1,27 & 122 & 23,6 & 310 & 1,27 & 82,3 & 92,4 & 84,0 & 1,02 & 0,91 & 0,96 \\
\hline Goyal e Jackson (7) & $\mathrm{Pl}$ & P2 & 7,62 & 7,62 & 4 & 0,25 & 1,00 & 1,27 & 122 & 23,6 & 310 & 1,91 & 64,5 & 72,7 & 65,5 & 1,02 & 0,90 & 0,96 \\
\hline Goyal e Jackson (7) & Q1 & Q2 & 7,62 & 7,62 & 4 & 0,25 & 1,00 & 1,27 & 122 & 19,9 & 310 & 2,54 & 51,4 & 48,9 & 45,4 & 0,88 & 0,93 & 0,91 \\
\hline Goyal e Jackson (7) & Rl & R2 & 7,62 & 7,62 & 4 & 0,25 & 1,00 & 1,27 & 274 & 21,4 & 310 & 1,27 & 33,5 & 31,1 & 31,1 & 0,93 & 1,00 & 0,96 \\
\hline Goyal e Jackson (7) & S1 & S2 & 7,62 & 7,62 & 4 & 0,25 & 1,00 & 1,27 & 274 & 20,9 & 310 & 1,91 & 23,0 & 24,3 & 24,4 & 1,06 & 1,00 & 1,03 \\
\hline Goyal e Jackson (7) & $\mathrm{Tl}$ & T2 & 7,62 & 7,62 & 4 & 0.25 & 1,00 & 1,27 & 274 & 20,7 & 310 & 2,54 & 19,4 & 20,6 & 21,2 & 1,09 & 1,03 & 1,06 \\
\hline Kim e Yang (8) & เ2-1 & L2-2 & 8,00 & 8,00 & 4 & 0,3175 & 1,27 & 1,50 & 144 & 25,5 & 387 & 2,40 & 63,7 & 65,7 & 65,8 & 1,03 & 1,00 & 1,02 \\
\hline Kim e Yang (8) & $\lfloor 4-1$ & $\llcorner 4-2$ & 8,00 & 8,00 & 8 & 0,3175 & 2,54 & 1,50 & 24 & 25,5 & 387 & 2,40 & 109,5 & 109,3 & 102 & 0,93 & 0,93 & 0,93 \\
\hline Kim e Yang (8) & L4-3 & L4-4 & 8,00 & 8,00 & 8 & 0,3175 & 2,54 & 1,50 & 240 & 25,5 & 387 & 2,40 & 49,0 & 47,0 & 47,1 & 0,96 & 1,00 & 0,98 \\
\hline Kim e Yang (8) & M2-1 & M2-2 & 8,00 & 8,00 & 4 & 0,3175 & 1,27 & 1,50 & 24 & 63,5 & 387 & 2,40 & 179,0 & 182,8 & 168,6 & 0,94 & 0,92 & 0,93 \\
\hline Kim e Yang (8) & M2-3 & M2-4 & 8,00 & 8,00 & 4 & 0,3175 & 1,27 & 1,50 & 144 & 63,5 & 387 & 2,40 & 102,8 & 113,5 & 100,2 & 0.97 & 0,88 & 0,93 \\
\hline Kim e Yang (8) & M2-5 & M2-6 & 8,00 & 8,00 & 4 & 0,3175 & 1,27 & 1,50 & 240 & 63,5 & 387 & 2,40 & 45,2 & 47,6 & 54,7 & 1,21 & 1,15 & 1,18 \\
\hline Kim e Yang (8) & M4-1 & M4-2 & 8,00 & 8,00 & 8 & 0,3175 & 2,54 & 1,50 & 24 & 63,5 & 387 & 2,40 & 207,7 & 204,6 & 186,7 & 0,90 & 0.91 & 0.91 \\
\hline \multirow[t]{3}{*}{ Kim e Yang (8) } & M4-3 & M4-4 & 8,00 & 8,00 & 8 & 0,3175 & 2,54 & 1,50 & 240 & 63,5 & 387 & 2,40 & 59,6 & 60,5 & 70,7 & 1,19 & 1,17 & 1,18 \\
\hline & & & & & & & & & & & & & & & & \multicolumn{2}{|c|}{ Global Mean } & 1,00 \\
\hline & & & & & & & & & & & & & & & & \multicolumn{2}{|c|}{ Standard Deviation } & 0,07 \\
\hline
\end{tabular}

where $A_{a}, A_{c}$ and $A_{s}$ are, respectively, the areas of steel l-section, concrete and reinforcements; $f_{y a}$, and $f_{y s}$ are, respectively, the yield stresses of steel I-section and reinforcements; and $f_{c k}$ is the compressive characteristic strength of concrete.

To determine the moment-curvature relationship the program starts considering an applied axial force $\mathrm{N}_{\mathrm{sz}}$ equal to $10 \%$ of the plastic resistance $\mathrm{N}_{\mathrm{REF}}$. If the process results in convergence, the program increases the applied force in more $10 \%$ of $\mathrm{N}_{\mathrm{REF}}$, and so on until convergence is not reached. From this point, cuts of $1 \%$ of $\mathrm{N}_{\mathrm{REF}}$ are made until there is convergence of the model again, yielding then, with $1 \%$ precision of $\mathrm{N}_{\mathrm{REF}}$, the column axial force resistance.

\section{Validation of results}

\subsection{Reinforced concrete columns}

To validate the procedure for calculation of reinforced concrete columns implemented via CSTMI, the authors have modeled columns subjected to combined compression and uniaxial bending studied by Araújo [6], who compared theoretical results obtained from a computer program implemented by him to results of several experiments by other researchers.

It is emphasized that, as a comparison with tests, all partial factors were considered unit. He also specified as unitary the value of $\alpha$, reduction factor on the characteristic strength of the concrete due to the long-term effects (Rüsch effect). The tested columns were subjected to constant bending moments. All these considerations have also been adopted in the numerical model.
Table 1 shows the test results compared to the results obtained by CSTMI.

In both tests performed by Goyal and Jackson [7], and in those performed by Kim and Yang [8], two columns with the same geometric characteristics and material (for example, the first line of the Table, columns A1 and A2) were evaluated for each series. Thus, there are two experimental results, $F_{u, \text { exp } 1}$ and $F_{u, \text { exp } 2}$, for each column series.

Samples of columns of the same series can be considered dependent on each other, thus should not be evaluated separately in order to not violate the principle of statistical independence. In this case, it may be used only the value of $F_{u \text { exp } 1}$, or only $F_{u \text {, exp2' }}$, or the average of the two values. It was evaluated the data of the ratios $R=F_{u, \text { CSTMI }} / F_{u, \text { EXP1 }}$ and $R=F_{u, \text { CSTMI }} / F_{u, \text { EXP2 }}$ for the couple of tests with the same characteristics, and it can be concluded that it is possible to take the average between the tests since they do not differ ( $p$-value $=0.357$, from the paired t-test at $5 \%$ significance).

The histogram of Figure 5 shows the frequency distribution for the $R$ mean values obtained for each tested pair of columns (for example, A1 and A2). It was observed that the distribution is normal ( $p$-value $>0.15$, using the Kolmogorov-Smirnov test).

The average value of the ratios $R=F_{u, \text { сSTMI }} / F_{u, \text { EXP }}$ was 1.0, with a standard deviation of 0.07 . In order to verify that the theoretical value calculated by CSTMI is equivalent to the test values, it was performed the t-test to compare if the average is equal to 1.0. The $\mathrm{p}$-value found was 0.887 , indicating that the average value does not differ from 1.0 so it can be stated that the column's resistance determined by CSTMI is equivalent to the test values. 
Figure 5 - Histogram of $\mathbf{R}$ ratios

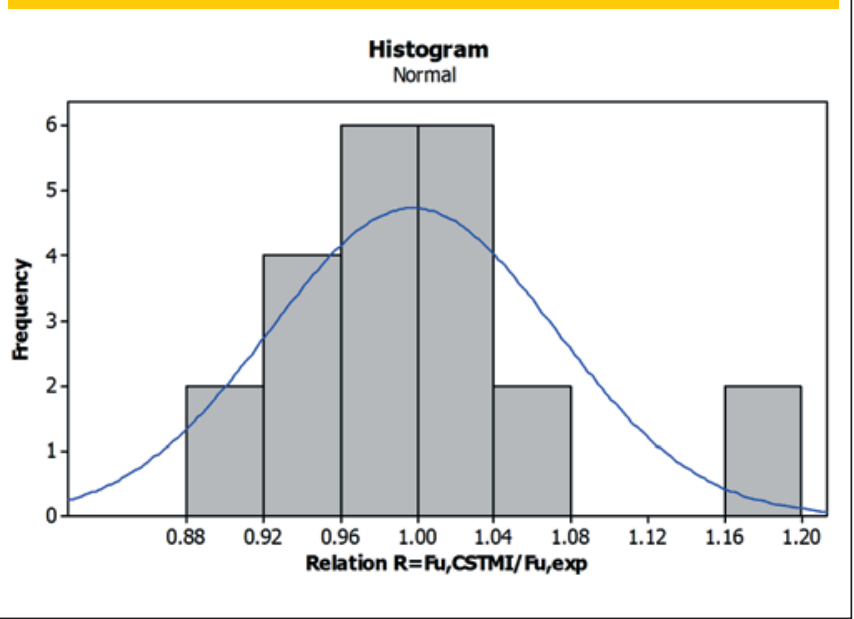

\subsection{Fully encased composite columns}

Composite columns subjected to combined compression and uniaxial bending studied by Kim [9] were modeled to validate the procedure of calculation of fully concrete encased steel I-section (SC) implemented at CSTMI program. The author raised an extensive database of experimental results of several researchers [10 to 16] with samples of fully encased composite columns, concrete-filled circular, and rectangular hollow sections.

The results of fully encased composite columns were divided into two categories: columns with 119 tests of bars subjected to axial compression; and beams-columns, with 136 tests of bars subjected to combined compression and uniaxial bending.

Since it is required an initial eccentricity to start the iterative process for the calculation of the column resistance, the category columns samples were disregarded. It was also removed the tests of beams-columns, beams with low density concrete, without reinforcement bars, and specimen with the occurrence of biaxial bending, remaining a sample of 87 experiments.

The tests were performed in simply supported columns with axial compression and lateral forces producing a constant bending moment along the bar. As the tests of reinforced concrete columns, it was also considered for the concrete of the composite columns the factor $\alpha=1.0$. All columns were divided into 10 longitudinal ele-

\section{Figure 6 - Box-plot of $R$ ratios for each method}

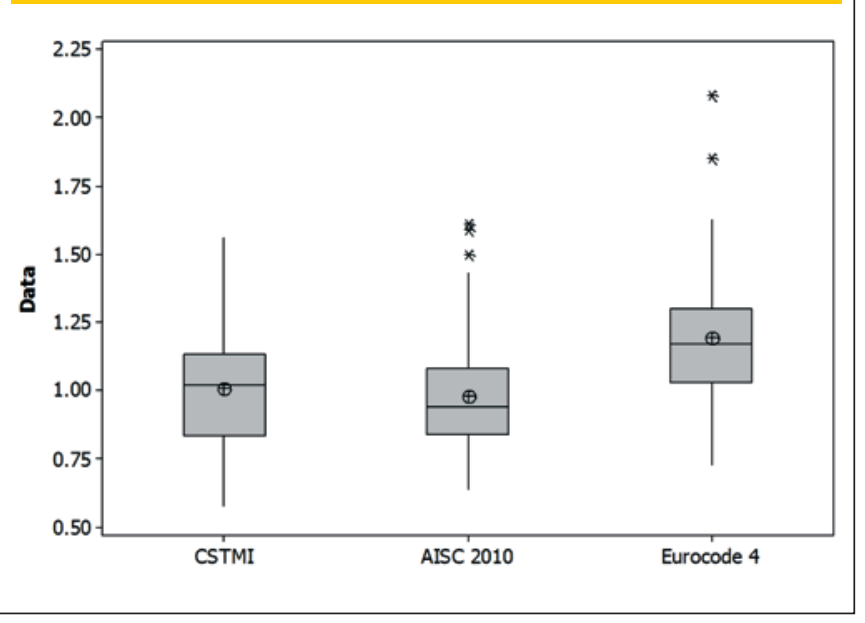

ments and the cross section was divided into elements of 3 and 4 sides of approximately $10 \mathrm{~mm}$.

Kim has compared the experimental data with the theoretical calculation from the procedures of ANSI/AISC 360-05 [17] (identical to ANSI/AISC 360-10 [18]) and EN 1994-1-1:2004 [19]. Table 3 lists the tests evaluated, with the characteristics of the columns, the applied eccentricities and the experimental resistance. It is also presented the $\mathrm{R}=\mathrm{N}_{\mathrm{R}, \mathrm{EXP}} / \mathrm{N}_{\mathrm{R}, \text { TEO }}$ ratios for each of the standards and with the use of CSTMI program.

It is observed that the $\mathrm{R}$ ratios for all of the evaluated methods presented great variability (for CSTMI the lowest value was $R=0.58$ and the highest, $R=1.56$ ). This shows the difficulty to calibrate a numerical method to results so different. With the elimination of outliers in the same test group (tests 106 to 109 of Han, 1992), the sample was reduced from 87 to 83 columns.

Table 2 lists the mean and standard deviation for the $\mathrm{R}$ ratio for the methods evaluated by Kim and the CSTMI. Figure 6 presents a box-plot illustrating this information.

For the CSTMI, it was obtained an average value of the ratio $R$ equals to 1.01 with a standard deviation of 0.20 . Figure 7 shows a dispersion of the $\mathrm{R}$ values for all tests calculated by CSTMI. The $95 \%$ confidence interval was set between 0.60 and 1.41 , ie., $95 \%$ of the $R$ values are in this range.

To verify the equivalence of theoretical to the test values, it was performed a $z$ test to compare if the mean is equal to 1.0. The

\section{Table 2 - Mean values of the R ratio for comparisons between the composite columns tests, implemented, and standards procedures}

\begin{tabular}{|ccccccccccc|} 
Methods & N & Mean & $\begin{array}{c}\text { Standard- } \\
\text { deviation }\end{array}$ & Minimum & $\begin{array}{c}\text { 1st } \\
\text { Quartile }\end{array}$ & Median & $\begin{array}{c}\text { 3rd } \\
\text { Quartile }\end{array}$ & Maximum \\
\hline CSTMI & 83 & 1.01 & 0.20 & 0.58 & 0.83 & 1.02 & 1.13 & 1.56 \\
\hline AISC 2010 & 83 & 0.98 & 0.22 & 0.64 & 0.84 & 0.94 & 1.08 & 1.61 \\
\hline EN 1994-1-1:2004 & 83 & 1.19 & 0.22 & 0.73 & 1.03 & 1.17 & 1.30 & 2.08 \\
\hline
\end{tabular}


Table 3 - Database of test results of fully encased composite columns

\begin{tabular}{|c|c|c|c|c|c|c|c|c|c|c|c|}
\hline & & & & & & & Steel S & ection & & Concret & Column \\
\hline liem & Source & Specimen & $\left(\mathrm{MPa}^{\mathrm{fy}}\right)$ & $\left(\mathrm{MPa}^{\mathrm{f}} \mathrm{a}\right)$ & (MPfa) & $(\stackrel{d}{d})$ & $(\stackrel{\mathrm{bf}}{\mathrm{mm}})$ & $(\stackrel{\mathbb{H}}{\mathrm{m}})$ & $(\mathrm{mm})$ & $\left(\begin{array}{l}\mathrm{bc} \\
(\mathrm{mm})\end{array}\right.$ & $\left(\begin{array}{l}\mathrm{hc} \\
(\mathrm{mm})\end{array}\right.$ \\
\hline 6 & Stevens (10) & FE3 & 218 & 17,4 & 270 & 304,8 & 203,2 & 21,22 & 14,15 & 305 & 406 \\
\hline 7 & Stevens $(10)$ & FE4 & 218 & 16,3 & 270 & 304,8 & 203.2 & 21,22 & 14,15 & 305 & 406 \\
\hline 8 & Stevens (10) & FE5 & 218 & 27,0 & 270 & 304,8 & 203,2 & 21,22 & 14,15 & 305 & 406 \\
\hline 9 & Stevens (10) & FE6 & 218 & 18,5 & 270 & 304,8 & 203,2 & 21,22 & 14,15 & 305 & 406 \\
\hline 10 & Stevens $(10)$ & FE7 & 218 & 18,5 & 270 & 304,8 & 203.2 & 21,22 & 14,15 & 305 & 406 \\
\hline 11 & Stevens (10) & FE8 & 218 & 19,3 & 270 & 304,8 & 203,2 & 21,22 & 14,15 & 305 & 406 \\
\hline 12 & Stevens $(10)$ & FE9 & 218 & 18,8 & 270 & 304,8 & 203,2 & 21,22 & 14,15 & 305 & 406 \\
\hline 13 & Stevens (10) & FE10 & 218 & 21,2 & 270 & 304,8 & 203,2 & 21,22 & 14,15 & 305 & 406 \\
\hline 14 & Stevens (10) & FEll & 218 & 20,7 & 270 & 304,8 & 203,2 & 21,22 & 14,15 & 305 & 406 \\
\hline 28 & Janss e Anslijn, (11) & 11.1 & 281 & 34,3 & 270 & 140 & 140 & 12 & 7 & 240 & 240 \\
\hline 29 & Janss e Anslijn, (11) & 11.2 & 281 & 33,1 & 270 & 140 & 140 & 12 & 7 & 240 & 240 \\
\hline 30 & Janss e Anslin, (11) & 11.3 & 281 & 28.8 & 270 & 140 & 140 & 12 & 7 & 240 & 240 \\
\hline 31 & Janss e Anslijn, (11) & 12.1 & 372 & 32,2 & 270 & 140 & 140 & 12 & 7 & 240 & 240 \\
\hline 32 & Janss e Anslijn, (11) & 12.2 & 372 & 31,2 & 270 & 140 & 140 & 12 & 7 & 240 & 240 \\
\hline 33 & Janss e Anslijn, (11) & 12.3 & 372 & 28,8 & 270 & 140 & 140 & 12 & 7 & 240 & 240 \\
\hline 34 & Janss e Anslinn, (11) & 13.1 & 267 & 33,2 & 270 & 220 & 110 & 9,2 & 5.9 & 210 & 320 \\
\hline 35 & Janss e Anslinn, (11) & 13.2 & 267 & 31,2 & 270 & 220 & 110 & 9.2 & 5,9 & 210 & 320 \\
\hline 36 & Janss e Anslijn, (11) & 13.3 & 267 & 30.6 & 270 & 220 & 110 & 9.2 & 5.9 & 210 & 320 \\
\hline 50 & Roik e Schwalbenhofer, (12) & V11 & 251 & 43,8 & 412 & 120 & 120 & 11 & 6,5 & 280 & 280 \\
\hline 51 & Roik e Schwalbenhofer, (12) & $\mathrm{V} 12$ & 251 & 43,8 & 412 & 120 & 120 & 11 & 6.5 & 280 & 280 \\
\hline 52 & Roik e Schwalbenhofer, (12) & V13 & 251 & 46,8 & 412 & 120 & 120 & 11 & 6,5 & 280 & 280 \\
\hline 53 & Roik e Schwalbenhofer, (12) & V21 & 335 & 46,8 & 412 & 152 & 160 & 9 & 6 & 280 & 280 \\
\hline 54 & Roik e Schwalbenhofer, (12) & V22 & 335 & 37,0 & 412 & 152 & 160 & 9 & 6 & 280 & 280 \\
\hline 55 & Roik e Schwalbenhofer, (12) & V23 & 335 & 37,0 & 412 & 152 & 160 & 9 & 6 & 280 & 280 \\
\hline 56 & Roik e Schwalbenhofer, (12) & V31 & 256 & 40,7 & 412 & 200 & 200 & 15,00 & 9,00 & 280 & 280 \\
\hline 57 & Roik e Schwalbenhofer, (12) & V32 & 256 & 40,7 & 412 & 200 & 200 & 15,00 & 9,00 & 280 & 280 \\
\hline 58 & Roik e Schwalbenhofer, (12) & v33 & 256 & 39,3 & 412 & 200 & 200 & 15,00 & 9,00 & 280 & 280 \\
\hline 59 & Roik e Schwalbenhofer, (12) & $\mathrm{v} 4 \mathrm{1}$ & 333 & 39,3 & 412 & 200 & 186 & 24,00 & 14,50 & 280 & 280 \\
\hline 60 & Roik e Schwalbenhofer, (12) & $\mathrm{v} 42$ & 333 & 42,2 & 412 & 200 & 186 & 24,00 & 14,50 & 280 & 280 \\
\hline 61 & Roik e Schwalbenhofer, (12) & V43 & 335 & 42,2 & 412 & 200 & 186 & 24,00 & 14,50 & 280 & 280 \\
\hline 65 & Roik e Schwalbenhofer, (12) & V111 & 306 & 40,1 & 412 & 152 & 160 & 9,00 & 6.00 & 280 & 280 \\
\hline 66 & Roik e Schwalbenhofer, (12) & V112 & 306 & 40,1 & 412 & 152 & 160 & 9,00 & 6,00 & 280 & 280 \\
\hline 67 & Roik e Schwalbenhofer, (12) & V121 & 237 & 40,1 & 412 & 120 & 120 & 11 & 0,5 & 280 & 280 \\
\hline 68 & Roik e Schwalbenhofer, (12) & V122 & 237 & 40,1 & 412 & 120 & 120 & 11 & 6.5 & 280 & 280 \\
\hline 69 & Roik e Schwalbenhofer, (12) & V123 & 237 & 40,1 & 412 & 120 & 120 & 11 & 6.5 & 280 & 280 \\
\hline 70 & Roik e Mangerig. (13) & 7 & 265 & 42,0 & 412 & 200 & 200 & 15,00 & 9,00 & 300 & 300 \\
\hline 71 & Roik e Mangerig, (13) & 8 & 265 & 42,0 & 412 & 200 & 200 & 15,00 & 9,00 & 300 & 300 \\
\hline 72 & Roik e Mangerig. (13) & 9 & 265 & 42,0 & 412 & 200 & 200 & 15,00 & 9,00 & 300 & 300 \\
\hline 73 & Roik e Mangerig, (13) & 10 & 265 & 42,0 & 412 & 200 & 200 & 15,00 & 9,00 & 300 & 300 \\
\hline 74 & Roik e Mangerig, (13) & 11 & 265 & 42,0 & 412 & 200 & 200 & 15,00 & 9,00 & 300 & 300 \\
\hline 75 & Roik e Mangerig, (13) & 12 & 265 & 42,0 & 412 & 200 & 200 & 15,00 & 9,00 & 300 & 300 \\
\hline 76 & Roik e Mangerig, (13) & 23 & 265 & 42,0 & 412 & 200 & 200 & 15,00 & 9.00 & 300 & 300 \\
\hline 77 & Roik e Mangerig, (13) & 24 & 265 & 42,0 & 412 & 200 & 200 & 15,00 & 9,00 & 300 & 300 \\
\hline 78 & Roik e Mangerig, (13) & 25 & 265 & 42,0 & 412 & 200 & 200 & 15,00 & 9,00 & 300 & 300 \\
\hline 79 & Roik e Mangerig, (13) & 26 & 265 & 42,0 & 412 & 200 & 200 & 15,00 & 9,00 & 300 & 300 \\
\hline 80 & Roik e Mangerig, (13) & 27 & 265 & 42,0 & 412 & 220 & 206 & 25,00 & 15,00 & 300 & 300 \\
\hline 81 & Roik e Mangerig, (13) & 28 & 265 & 42,0 & 412 & 220 & 206 & 25,00 & 15,00 & 300 & 300 \\
\hline 82 & Roik e Mangerig, (13) & 29 & 265 & 42,0 & 412 & 220 & 206 & 25,00 & 15,00 & 300 & 300 \\
\hline 83 & Roik e Mangerig, (13) & 30 & 265 & 42,0 & 412 & 220 & 206 & 25,00 & 15,00 & 300 & 300 \\
\hline 84 & Mirza e Hyttinen, (14) & RHB-1 & 287 & 27,2 & 554 & 96 & 100 & 8.00 & 5,00 & 240 & 240 \\
\hline 85 & Mirza e Hyttinen, (14) & RHB-2 & 287 & 27.2 & 554 & 96 & 100 & 8.00 & 5,00 & 240 & 240 \\
\hline 86 & Mirza e Hyttinen, (14) & RHB-3 & 287 & 27,7 & 554 & 96 & 100 & 8,00 & 5,00 & 240 & 240 \\
\hline 87 & Mirza e Hyttinen, (14) & RHB-4 & 305 & 25,9 & 622 & 96 & 100 & 8.00 & 5.00 & 240 & 240 \\
\hline 88 & Mirza e Hyttinen, (14) & RHB-4A & 287 & 25,1 & 554 & 96 & 100 & 8.00 & 5,00 & 240 & 240 \\
\hline 90 & Mirza e Hyttinen, (14) & RNHB-1 & 305 & 27,5 & 622 & 96 & 100 & 8.00 & 5,00 & 240 & 240 \\
\hline 91 & Mirza e Hyttinen, (14) & RNHB-2 & 305 & 27,5 & 622 & 96 & 100 & 8.00 & 5,00 & 240 & 240 \\
\hline 92 & Mirza e Hyttinen, (14) & RNHB-3 & 287 & 26,8 & 554 & 96 & 100 & 8,00 & 5,00 & 240 & 240 \\
\hline 93 & Mirza e Hyttinen, (14) & RNHB-4 & 287 & 27,2 & 554 & 96 & 100 & 8,00 & 5,00 & 240 & 240 \\
\hline 95 & Mirza e Hyttinen, (14) & RHNB-1 & 305 & 27,5 & 622 & 96 & 100 & 8,00 & 5,00 & 240 & 240 \\
\hline 96 & Mirza e Hyttinen, (14) & RHNB-2 & 305 & 27,5 & 622 & 96 & 100 & 8,00 & 5,00 & 240 & 240 \\
\hline 97 & Mirza e Hyttinen, (14) & RHNB-3 & 305 & 25,9 & 622 & 96 & 100 & 8.00 & 5,00 & 240 & 240 \\
\hline 98 & Mirza e Hyttinen, (14) & RHNB-4 & 305 & 25,9 & 622 & 96 & 100 & 8,00 & 5,00 & 240 & 240 \\
\hline 100 & Roik e Diekmann, (15) & 11 & 279 & 46,6 & 270 & 200 & 200 & 15,00 & 9,00 & 300 & 300 \\
\hline 101 & Roik e Diekmann, (15) & 12 & 279 & 46,6 & 270 & 200 & 200 & 15,00 & 9.00 & 300 & 300 \\
\hline 102 & Roik e Diekmann, (15) & 13 & 279 & 46,6 & 270 & 200 & 200 & 15,00 & 9,00 & 300 & 300 \\
\hline 103 & Roik e Diekmann, (15) & 14 & 242 & 46,6 & 270 & 152 & 160 & 9 & 6 & 300 & 300 \\
\hline 104 & Roik e Diekmann, (15) & 15 & 392 & 46,6 & 270 & 200 & 200 & 15,00 & 9,00 & 300 & 300 \\
\hline 105 & Roik e Diekmann, (15) & 16 & 279 & 46,6 & 270 & 200 & 200 & 15,00 & 9.00 & 300 & 300 \\
\hline 110 & Han e Kim, (16) & AH2-E2-80 & 310 & 21,4 & 275 & 100 & 100 & 8 & 6 & 160 & 160 \\
\hline 111 & Han e Kim, (16) & AH2-E4-80 & 310 & 21,4 & 275 & 100 & 100 & 8 & 6 & 160 & 160 \\
\hline 112 & Han e Kim, (16) & AH2-E8-80 & 310 & 21,4 & 275 & 100 & 100 & 8 & 6 & 160 & 160 \\
\hline 113 & Han e Kim, (16) & BH2-E2-80 & 310 & 21,4 & 275 & 100 & 100 & 8 & 6 & 160 & 160 \\
\hline 114 & Han e Kim, (16) & BH2-E4-80 & 310 & 21,4 & 275 & 100 & 100 & 8 & 6 & 160 & 160 \\
\hline 115 & Han e Kim, (16) & BH2-E8-80 & 310 & 21,4 & 275 & 100 & 100 & 8 & 6 & 160 & 160 \\
\hline 116 & Han e Kim, (16) & $\mathrm{CH} 1-\mathrm{E} 2-80$ & 310 & 21,4 & 275 & 100 & 75 & 4,50 & 3,20 & 160 & 160 \\
\hline 117 & Han e Kim, (16) & CH1-E4-80 & 310 & 21,4 & 275 & 100 & 75 & 4,50 & 3,20 & 160 & 160 \\
\hline 118 & Han e Kim, (16) & $\mathrm{CH} 1-\mathrm{E} 8-80$ & 310 & 21,4 & 275 & 100 & 75 & 4,50 & 3.20 & 160 & 160 \\
\hline 119 & Han e Kim, (16) & CH2-E2-80 & 310 & 21,4 & 275 & 100 & 100 & 8 & 6 & 160 & 160 \\
\hline 120 & Han e Kim, (16) & $\mathrm{CH} 2-\mathrm{E} 4-80$ & 310 & 21,4 & 275 & 100 & 100 & 8 & 6 & 160 & 160 \\
\hline 121 & Han e Kim, (16) & $\mathrm{CH} 2-\mathrm{E} 8-80$ & 310 & 21,4 & 275 & 100 & 100 & 8 & 6 & 160 & 160 \\
\hline 122 & Han e Kim, (16) & DH2-E2-80 & 310 & 21,4 & 275 & 100 & 100 & 8 & 6 & 160 & 160 \\
\hline 123 & Han e Kim, (16) & DH2-E4-80 & 310 & 21,4 & 275 & 100 & 100 & 8 & 6 & 160 & 160 \\
\hline 124 & Han e Kim, (16) & DH2-E8-80 & 310 & 21,4 & 275 & 100 & 100 & 8 & 6 & 160 & 160 \\
\hline & & & & & & & & & & & \\
\hline & & & & & & & & & & & \\
\hline
\end{tabular}




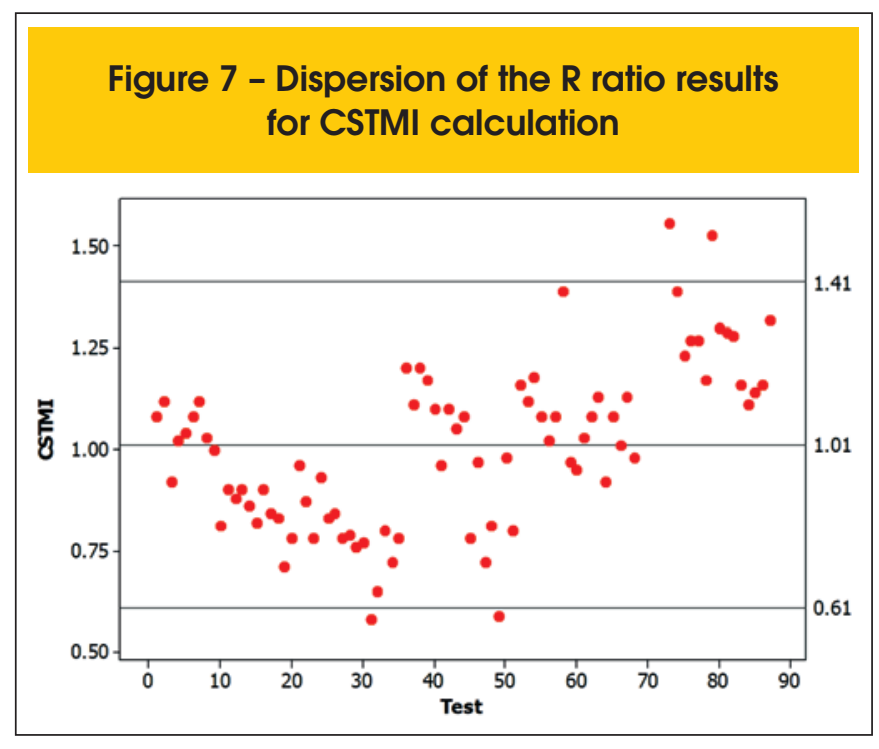

CSTMI method has obtained acceptable result ( $p$-value $=0.746$ at $5 \%$ significance). It is noted that a $p$-value higher than $5 \%$ indicates no difference between the mean value and 1.0 so that the result obtained with CSTMI is satisfactory with a better quality than the result obtained by the ANSI/AISC 360-10 [18] (p-value equal to 0.377 ).

From this analysis it can be concluded that the procedure implemented to determine the ultimate axial force of fully encased composite columns is appropriate in general, with better approximations than the ANSI/AISC 360-10 [18] and EN 1994-1-1:2004 [19].

\section{Conclusions}

For reinforced concrete columns, CSTMI was adequate, since the resistance results proved compatible with the samples of $44 \mathrm{col}-$ umns tested by other researchers.

For fully encased composite columns, the program CSTMI was compared with a sample of 87 tests by other researchers. The numerical results were calibrated with the experimental results for many slenderness ratios.

It is concluded that the implemented procedure provides good results for the determination of the resistance of reinforced concrete columns and fully encased composite columns. This procedure can be considered valid as a general method for calculating columns subjected to combined compression and uniaxial bending.

\section{Acknowledgements}

The authors are grateful to Brazilian agencies for research CNPq, CAPES and FAPEMIG and CODEME Engenharia S.A., for supporting this work.

\section{References}

[1] ASSOCIAÇÃO BRASILEIRA DE NORMAS TÉCNICAS. NBR 6118: Projeto de Estruturas de Concreto - Procedimento. Rio de Janeiro, 2014.
[2] CALDAS, R.B., SOUZA JR, J.B.M., Cálculo de Seções Transversais Mistas. Ouro Preto, 2004.

[3] CALDAS, R.B., Análise Numérica de Pilares Mistos AçoConcreto. Dissertação de Mestrado, Escola de Minas, Universidade Federal de Ouro Preto, 2004.

[4] CALDAS, R.B., Análise Numérica de Estruturas de Aço, Concreto e Mistas em Situação de Incêndio. Tese de Doutorado, Universidade Federal de Minas Gerais, 2008.

[5] GEUZAINE, C., REMACLE, J. Gmsh: a three-dimensional finite element mesh generator with built-in pre- and post-processing facilities. International Journal for Numerical Methods in Engineering, 79(11), pp. 1309-1331, 2009.

[6] ARAÚJO, J.M. Pilares Esbeltos de Concreto Armado. Parte 1: Um modelo não linear para análise e dimensionamento. Teoria e Prática na Engenharia Civil, Porto Alegre, n.18, p.81-93, 2011.

[7] GOYAL, B.B., JACKSON, N. Slender concrete columns under sustained load. Journal of the Structural Division, ASCE, v. 97, n.11, p.2729-50, 1971.

[8] KIM, J.K., YANG, J.K. Buckling behavior of slender highstrength concrete columns. Journal of Engng. Struct., v. 17, n.1, p.39-51, 1995.

[9] KIM, D.K., A Database for Composite Columns. Dissertação de Mestrado, Georgia Institute of Technology, 2005.

[10] STEVENS, R.F., Encased Stanchions. Struct. Engineering, v.43, p.59-66, 1965.

[11] JANSS, J., ANSLIJN, R. Le Calcul des Charges Ultimes des Colonnes Métalliques Enrobées de Béton. Rapport MT 89, C.R.I.F., Brussels, 1974.

[12] ROIK, K., SCHWALBENHOFER, K. Untersuchung der Verbundwirkung zwischen Stahlprofil und Beton hein Stützenkonstruktionen, Studiengesellschaft für Anwendungstechnik von Eisen und Stahl e.V., Forschungsvorhaben, p.51, Dusseldorf, 1989.

[13] ROIK, K., MANGERIG, I. Zur Traglast von einbetonierten Stahlprofilstützen unter Berücksichtigung des Langzeitverhaltens von Beton, Der Stahlbau, 1990.

[14] MIRZA, S., HYTTINEN, V., HYTTINEN, E. Physical Tests and Analyses of Composite Steel Concrete Beam-Columns, Journal of Structural Engineering, ASCE, 122(11), 13171326, 1996.

[15] ROIK, K., DIEKMANN, C. Experimental Studies on Composite Columns Encased in Concrete Following Loading, Der Stahlbau, 58(6), 161-164, 1989.

[16] HAN, D.J., KIM, K.S. A study on the Strength and Histeretic Characteristics of Steel Reinforced Concrete Columns, Journal of the Architectural Institute of Korea, 11(4), 183-190, 1995.

[17] AMERICAN INSTITUTE OF STEEL CONSTRUCTION. Specification for Structural Steel Buildings. ANSI/AISC 360-05.

[18] AMERICAN INSTITUTE OF STEEL CONSTRUCTION. Specification for Structural Steel Buildings. ANSI/AISC 360-10.

[19] EUROPEAN COMMITTEE FOR STANDARDIZATION. EN 1994-1-1: Eurocode 4 - Design of Composite Structures. Part 1-1: General rules and rules for buildings. Brussels, 2004. 